\title{
The Four-Seven Debate of Korean Neo-Confucianism and the Moral Psychological and Theistic Turn in Korean Philosophy
}

\author{
Bongrae Seok $(\mathbb{D}$ \\ Department of Humanities, Alvernia University, Reading, PA 19607, USA; bongrae.seok@alvernia.edu
}

Received: 21 September 2018; Accepted: 15 November 2018; Published: 19 November 2018

check for updates

\begin{abstract}
This paper discusses how Korean Neo-Confucian philosophers in the Joseon dynasty (1392-1910) explained the moral nature of the mind and its emotions. Among the philosophical debates of Korean Neo-Confucianism, the author of the paper focuses on the Four-Seven Debate (a philosophical debate about the moral psychological nature of the four moral emotions and the seven morally indiscrete emotions) to analyze its $l i-q i$ metaphysics (a philosophical explanation of the universe through the intricate and interactive relation between the two cosmic processes, $l i$ and $q i$ ) and its conflicting viewpoints on the moral psychological nature of emotion. Because of the ambiguities and inconsistencies in the Neo-Confucian explanation, specifically those of the Cheng-Zhu schools of Neo-Confucianism on the nature and functions of the mind, Korean Neo-Confucians struggled to bring Neo-Confucian $l i-q i$ metaphysics to the moral and practical issues of the human mind and moral cultivation. Later in the Joseon dynasty, some Korean Neo-Confucians discussed the fundamental limitations of $l i-q i$ metaphysics and developed their explanations for the goodness of the moral mind and the world from an alternative (i.e., theistic) viewpoint.
\end{abstract}

Keywords: Korean Neo-Confucianism; the Four-Seven Debate; $l i$ and $q i$; moral metaphysics; moral psychology; theistic turn

\section{Introduction: Korean Neo-Confucianism and the Moral Goodness of the Mind}

Korean Neo-Confucian philosophers in the Joseon dynasty (1392-1910) discussed the moral goodness of the mind and the nature of human beings through the ultimate order of the universe. Specifically, they raised and discussed deep and challenging questions of moral metaphysics and moral psychology: How do the world and the mind interact and follow the same principles of the Neo-Confucian universe? How are the good and evil nature of the mind and its emotions explained? How are Confucian virtues and their foundations in the naturally given abilities of the mind explained? Over the period of the Joseon dynasty, Korean Neo-Confucians explored and developed their answers to these questions with careful explanations and rigorous analyses. They also elaborated their views and sharpened their arguments by actively engaging in philosophical debates. Although most of the debates were run by Neo-Confucian scholar-officials who were often politically active and socially engaged, the philosophical significance of the debates should not be overshadowed by their political interest and party affiliations. These debates were seriously philosophical and highly intellectual disputes that cast doubts on some of the fundamental principles of Neo-Confucianism. In this paper, I will explore, discuss, and explain the unique philosophical tradition of Korean Neo-Confucianism in the Joseon dynasty by focusing on how it explained the moral goodness of the mind and the world.

There are different ways to interpret and understand Korean intellectual tradition in the Joseon dynasty. The most popular interpretation of Korean philosophy in the Joseon dynasty is to characterize it as the study of nature (xing, 性) and the cosmic order ( $l i$, 理) in accordance with Cheng Yi 
(程頣, 1033-1107) and Zhu Xi's (朱喜, 1130-1200) Neo-Confucian philosophy. Although Wang Yangming's (王陽明, 1472-1529) Neo-Confucianism was studied by a few Korean Neo-Confucians such as Nam Un-Gyung (南經, 1529-1994), Jang Yu (張維, 1588-1638), and Jeong Che-Du (鄭齊斗， 1649-1736), the mainstream of Neo-Confucianism in the Joseon dynasty was Sunglihak/Xinglixue (性理學, the study of nature and the order of the universe) or Jujahak/Zhuxixue (朱子學, the study of Zhu Xi's teaching). ${ }^{1}$ In this paper, however, I will interpret Korean Neo-Confucianism in the Joseon dynasty from the perspective of the moral psychological orientation developed in the 16th and 17th centuries and the theistic turn developed in the 18th and 19th centuries. I will discuss how Korean philosophers in the Joseon dynasty, specifically in the Four-Seven Debate and the following debates, explained the moral goodness of the mind and how their explanations inspired a critical and analytic approach to the Neo-Confucian discourse of $l i$ and $q i$ and influenced the theistic orientations of the later centuries of Korean philosophy. More specifically, from the perspective of Korean Neo-Confucians' effort to explain, analyze, and emphasize the philosophical significance of the moral mind and emotions, I will argue that the Four-Seven Debate, despite its original intention to make a consistent and comprehensive philosophy of morality and moral psychology, showed the fundamental limitations of Neo-Confucianism. As revealed in the process of the Four-Seven Debate, the version of Neo-Confucianism founded and developed by Cheng Yi and Zhu Xi did not clearly and consistently explain the moral goodness of the mind. Since the Cheng-Zhu Neo-Confucianism integrated the cosmology of $l i$ (理) and $q i$ (氣) (a metaphysical explanation of how the universe comes to exist and change with its underlying principles and processes such as $l i$ and $q i$ ) and its normative order (the moral order of goodness and virtue in the world), it often provided ambiguous and inconsistent explanations of how the mind and its emotions receive innately good moral nature and how they cultivate moral virtues.

In what follows, I will take three steps in discussing the uniqueness of Korean Neo-Confucianism in its explanation of the moral goodness of the inner mind and the normative order of the outer world. First, I will discuss how Song Neo-Confucianism, specifically that of Cheng Yi and Zhu $\mathrm{X}$, explained the nature of moral goodness. This general overview will help us to understand the historical and philosophical background of Korean Neo-Confucianism, which is often indiscriminately and generically characterized as a philosophical follower or an intellectual heir to the Cheng-Zhu Neo-Confucianism (Cheng Yi and Zhu Xi's Neo-Confucianism, which emphasizes the penetrating cosmic unity and dynamic forces in the world). Second, I will discuss the Four-Seven Debate, a major philosophical debate in Korean Neo-Confucianism, and analyze its philosophical messages and implications. Particularly, I will explain how the participants of the debate attempted to disambiguate and overcome the inconsistencies of Cheng Yi and Zhu Xi's Neo-Confucianism in its explanation of moral emotions, and I will analyze how they developed their own theories of moral goodness of the mind. Although the Korean Neo-Confucians who participated in the Four-Seven Debates were not the followers of the Lu-Wang School of Neo-Confucianism, they focused on the mind and its functions in the cultivation of moral virtues. ${ }^{2}$ Third, I will discuss the theistic orientation of Korean philosophy in the 18th and 19th centuries from the viewpoint of Korean philosophers' efforts to resolve the inconsistencies of Neo-Confucianism and the philosophical tension raised by the early debates such as the Four-Seven Debate.

1 In addition to the two well-recognized schools, there is another school of Neo-Confucianism discussed by several scholars. It is called the Hu-Liu school, named after Hu Hong (胡宏, 1106-1161) and Liu Zongzhou (劉宗周 1578-1645). According to some scholars, the lineage of the school goes back to early Neo-Confucians such as Zhou Dunyi, Zhang Zai, and Cheng Hao. Jeong (Jeong 2016, p. 67) explained that Yulgok Yi I's (a leading Korean Neo-Confucian in the Joseon dynasty) philosophy was closer to Zhang Zai and Hu Hong's Neo-Confucianism than to the Cheng-Zhu's Neo-Confucianism.

2 The Lu-Wang (陸王) school was a Neo-Confucian school founded by Lu Jiuyuan (陸九淵, 1139-1192) and Wang Yangming (王陽明, 1472-1529), often called the school of xin (i.e., the school of the Confucian heart-mind). 


\section{Neo-Confucianism, Its Cosmology, and Moral Metaphysics}

As a philosophical successor of classical Confucianism (i.e., the Confucianism of Confucius, Mencius, Xunzi, and other Confucian philosophers in the pre-Qin era), Neo-Confucianism is a renovated version of Confucianism of the Song and later dynasties of China. Neo-Confucianism expanded its moral horizon by developing comprehensive philosophical theories of moral virtues and a good life from the perspective of the governing order of the universe and the moral metaphysics of the mind. ${ }^{3}$ For example, Cheng Yi and $\mathrm{Zhu} \mathrm{Xi}$ introduced and discussed a set of metaphysical principles and explained the penetrating and universal order that integrates the outer universe and the inner moral mind. Specifically, they believed that the universe and its metaphysical and moral nature can be explained by the two foundational processes $l i$ and $q i$. $L i$ (理) is the inherent pattern and the governing order of the universe. It is the foundation of the true and original nature of things and what they should ideally become. $Q i$ (氣), on the other hand, is the foundation of the concrete, local, dynamic, and physical properties of the universe. It is the force and energy behind the physical processes and diverging tendencies of individual objects. It takes tangible forms, serves particular physical functions, and stimulates dynamic changes in the universe. With $l i$ (generative, penetrating, coherent order, and unity), $q i$ (interactive, localized, physically diversifying energy), and their intricate interplay, Cheng Yi and Zhu Xi explained the nature of the mind, morality, and the generative processes of the universe.

As a theory of cosmology or moral metaphysics, the Cheng-Zhu Neo-Confucianism provided or at least attempted to provide a systematic explanation of the reality and goodness of the universe. According to them, everything comes to exist and change in accordance with universal principles that are not arbitrary or random. However, it is debatable whether the Cheng-Zhu approach provided a sufficient and successful explanation of moral properties, specifically moral properties of the mind. From the perspective of moral metaphysics, if everything is an intricate combination of $l i$ and $q i$, moral properties are no exception: They are explained by the interactivity of $l i$ and $q i$. From the perspective of moral agency and moral cultivation, however, the Cheng-Zhu approach can be inconsistent or incomplete. If everything comes out of the same principles and processes such as $l i$ and $q i$, why are some intentions and emotions good, but others are evil? As the underlying foundations of the cosmic processes, $l i$ and $q i$ are responsible for both the moral and immoral properties of the world. Because of this morally indiscrete nature of $l i$ and $q i$, the unique and distinctive nature of moral properties such as moral goodness, normativity, and virtue are not fully explained by Neo-Confucian $l i-q i$ metaphysics. Since $l i$ and $q i$ are involved in both the existence and the morality of the world, the clear and full distinction between ontology and morality is not made in Neo-Confucian philosophy. Additionally, explaining the moral nature of the mind is another challenge to the Cheng-Zhu Neo-Confucianism. Since the mind consists of the constant nature (xing, 性) that reflects the goodness of the universe and, at the same time, varying emotions (qing, 情) that can be evil, it is not easy to explain the intrinsically moral but spontaneously aroused emotional states of the mind that Mencius (2A6, 6A6) characterized as the foundation of Confucian virtues.

Usually, theories of metaphysics or cosmology explain what and how things happen in the world through their intrinsic nature (ontology) and origination (cosmology). They explain the function, process, and existence of reality through the ultimate causes or elements of the universe. From this general viewpoint, they provide answers to questions such as, "What is $\mathrm{x}$ and how does it come to exist?" However, they do not necessarily explain "what x ought to do" or "what x should become". As many philosophers (Hume 1739/1975; Moore 1903/2004) have pointed out, moral properties, unlike metaphysical or ontological properties, are related to the prescriptive, evaluative, or normative

3 Broadly, Neo-Confucianism is defined as "a category employed to describe a set of 'family resemblances' discerned across clusters of philosophical ideas, technical terms, arguments, and writings ... in other words, concepts, ideas, and discourse rather than schools" (Makeham 2010, p. xii). See (Angle and Tiwald 2017) for a general explanation of Neo-Confucianism. 
(i.e., non-descriptive) aspects of the world. They relate to what one ought to do and what should ideally happen in the world, not to what is happening in the world. ${ }^{4}$ For this reason, $l i$ and $q i$, as metaphysical elements or principles, do not discretely or exclusively explain the moral nature of the mind independently of its metaphysical origination and constitution. ${ }^{5}$ The difference, or conflict, between metaphysical cosmology and moral psychology, therefore, is a formidable philosophical challenge to those Neo-Confucians who wished to develop a consistent explanation of moral goodness in the minds of virtuous individuals. This is exactly the conflict or tension one could observe in the philosophical debates of Korean Neo-Confucianism in the Joseon dynasty.

One can find excellent introductions and in-depth discussions of Neo-Confucianism in recent publications (Angle 2009; Angle and Tiwald 2017; Bol 2008; Ching 2000; Huang 2014; Makeham 2010). According to them, Neo-Confucianism was not just a philosophy of personal virtues and ethics, but also a comprehensive theory of cosmology, metaphysics, and social-political philosophy. Perhaps, the intellectual endeavor to build a consistent and comprehensive system of philosophy was one of the important strengths of Neo-Confucianism. Currently, however, most Neo-Confucian scholarship focuses on the ethical and political dimensions more than the cosmological or metaphysical dimensions of Neo-Confucianism, not simply because the metaphysical or mythological theories of Neo-Confucianism were not continuous or compatible with modern science, but also because their hidden ontological biases or parochialism favor the Heavenly Principle (tianli 天理) and the ruling elites over foreign barbarians, commoners, females, and people with personal desires (人欲) and subjective feelings (Ching 2000). The major concern here is that the unitary and monistic metaphysical schemes of Neo-Confucianism or Confucianism in general may not serve as the aspirational and guiding moral foundation for pluralistic, egalitarian, and democratic society (Angle 2012; Chan 2014; Kim 2014; Tan 2004). For this reason, metaphysical Confucianism is often discussed independently of or in total separation from Confucianism as a public culture or as a political philosophy (Kim 2014). In this paper, however, I will focus more on the logical gap or conceptual incommensurability between moral metaphysics and moral psychology within the Cheng-Zhu school from the perspective of the philosophical debates in the Joseon dynasty. In their philosophical analyses, some Korean philosophers in the Joseon dynasty realized that even within the unitary and generative Neo-Confucian system of $l i$ and $q i$, moral mind and emotions were not fully and properly explained.

\section{Korean Neo-Confucianism in the Joseon Dynasty}

As a philosophical tradition that integrated the ultimate order of the universe and the virtue of human beings, Neo-Confucianism (specifically the Cheng-Zhu Neo-Confucianism) explained Confucian ideals of ren, yi, li, and zhi (仁義禮智, compassion, righteousness, ritual propriety, and wisdom) through the dialectic interfusion between $l i$ and $q i$. The interaction between $l i$ and $q i$, however, is not necessarily smooth, consistent, and mutually complementary, as the Chinese Neo-Confucians in the Song dynasty would have thought. The gap or inconsistency between moral metaphysics (how $l i$ and qi generate a myriad of things in the universe) and moral psychology (how the mind functions to generate moral emotions) was a major philosophical challenge to Korean Neo-Confucians of the Joseon dynasty. The two major philosophical debates of Korean Neo-Confucianism, the Four-Seven Debate (Sachil Nonjaeng, 四七論爭, 1559-1572, a philosophical debate about the moral psychological nature of the four innately moral emotions and the seven ordinary emotions) and the Horak Debate (Horak Nonjaeng, 湖洛論爭, 1712-1724, a philosophical debate about the nature of the unaroused and pure state of the mind) started when Korean Neo-Confucians realized that the nature of the mind and its emotions were not fully and naturally explained by the complementary interactivity between the

4 (Hume 1739/1975) pointed out that a statement of moral ought is not justified by a statement of fact. In a similar context, (Moore 1903/2004) argued that moral properties cannot be explained by natural properties.

5 The mind can represent and understand how and why things happen, but it can also represent and intend how things should (ideally) happen in its understanding of moral values and virtues. 
$l i$ and $q i$ of Neo-Confucian metaphysics. Some Neo-Confucians argued that the mind is intrinsically good since the mind inherits the ordered pattern (li) of the universe. Others argued that the mind is not necessarily good because its specific states and functions come to exist by the energy of $q i$ that is not necessarily consistent or regularized (i.e., unbalanced or uneven). The main concern of Korean Neo-Confucians, therefore, was to find a conceptually consistent and practically effective way to integrate the cosmic principles of $l i$ (理), $q i$ (氣), xing (性, nature), and xin (心, mind), and to explain the nature of the mind and its emotions that are partially good and partially evil, partially $l i$ and partially qi.

Regardless of their philosophical differences, Korean Neo-Confucians accepted the overarching philosophical framework of Confucianism and defended their philosophical legitimacy by citing the alleged philosophical authority of the Cheng-Zhu Neo-Confucianism. Generally speaking, they all agreed and accepted the same philosophical discourse of Neo-Confucianism (i.e., the philosophical discussion and explanation of the universe and the nature of moral virtue through xing (性, the inherent nature of things), $l i$ (理, the governing order of the universe), $q i$ (氣, the dynamic force of the universe), and $\operatorname{xin}$ (心, the Confucian heart-mind)). Unfortunately, the inconsistent and ambiguous details of $l i-q i$ metaphysics (a philosophical explanation of the universe through the intricate and interactive relation between the two cosmic processes $l i$ and $q i$ ) of the Cheng-Zhu Neo-Confucianism raised a formidable difficulty to Korean Neo-Confucians, as the Four-Seven Debate and the Horak Debate demonstrated.

Some scholars believe that the irresolvable philosophical conflicts in Neo-Confucian debates in the Joseon dynasty were exacerbated by the underlying political conflicts that most Korean Neo-Confucians participated in. ${ }^{6}$ Korean Neo-Confucians in the Joseon dynasty were mostly scholar-officials with specific party affiliations, and they often fought for political hegemony along with philosophical or ideological dominance: Bloody political purges and struggles were not infrequent throughout the history of the Joseon dynasty. However, independently of political issues, debates of Korean Neo-Confucianism had deep philosophical significance. In many debates, Korean Neo-Confucians engaged in rigorous philosophical argumentations and analyses. They disambiguated and analyzed abstract and metaphysical theories of Neo-Confucianism to explain the moral psychological nature of the Confucian heart-mind. Additionally, when they realized the philosophical challenge inherent in Neo-Confucian $l i-q i$ metaphysics, they did their best to resolve its conflicting details by developing new interpretations of the mind and its moral nature. In fact, Korean Neo-Confucianism is a great philosophical tradition of moral psychology that focused on the mind and its emotional energy at the foundation of moral virtues. ${ }^{7}$ The Four-Seven Debate delivered these intellectually stimulating characteristics of Korean philosophy.

\section{The Four-Seven Debate}

The Four-Seven Debate was a philosophical debate over the moral psychological nature of the two distinct groups of emotions. In this debate, Korean Neo-Confucians discussed whether the four moral emotions (i.e., the four innate and morally specific emotions discussed in the Mencius (孟子), such as the emotions of pity and compassion (惻隱), shame and dislike (差惡), compliance and deference (辭讓), and right and wrong (是非) are fundamentally different from the seven feelings (i.e., the seven

6 Takahashi's (Takahashi 1929/2001) discussion of Korean Neo-Confucianism was close to this type of interpretation. He explained Toegye's and Yulgok's (the two major philosophers of Korean Neo-Confucianism) philosophical views along the lines of party politics. According to him, Toegye was the founder of the li school (主理派), and Yulgok was the founder of the $q i$ school (主氣派). From the perspective of politics, the two groups were in direct conflict ( $l i$ against $q i$ and the Eastern party (東人) against the Western party (西人). However, from the viewpoint of philosophy, they were not necessarily conflicting or contradicting with each other. For example, it is wrong to say that Yulgok was the founder of the $q i$ school (主氣派). He did not believe in the ontological dominance of $q i$ : He believed that everything is a particular combination of $l i$ and $q i$. He even said that "it is a mistake to conclude that filthy things do not have principle [li]" (Yulgok's letter to Ugye's second letter) (Kalton 1994, p. 119).

7 See (Choe 2009) for the mentalizing tendency of Korean Neo-Confucianism. 
ordinary, morally neutral emotions listed in the Book of Rites (禮記), such as joy, anger, grief, fear, love, hate, and desire (喜怒愛懼哀惡欲). ${ }^{8}$ The two major discussants of the debate, Toegye (退溪, Yi Hwang 李滉 1501-1570) and Kobong (高, Ki Daesung 奇大升 1527-1572), explored and discussed the moral psychological nature of the Four and the Seven through Neo-Confucian $l i-q i$ metaphysics. ${ }^{9}$ The debate started when the Korean Neo-Confucians realized that a linear and contrastive explanation of the Four and the Seven through $l i$ and $q i$ did not work. ${ }^{10}$ That is, the explanation that the Four were always good because of $l i$ but the Seven could be evil because of $q i$ was not consistent with some of the fundamental doctrines of Neo-Confucian metaphysics: $L i$ and $q i$ are different but not separated from each other (不相雜 不相離) and everything is under their mutual interaction. Then, how could the difference between the Four and the Seven be explained by $l i$ and $q i$ ?

Toegye argued that the Four and the Seven are different emotions because the morally specific (i.e., morally dedicated, pure, and normative) nature of the Four is explained by li's exclusive generation (libal 理發, generation or issuance by li) of the Four but not of the Seven. Kobong, however, argued that the Four and the Seven are not essentially different emotions because they are all aroused states of the mind caused by qi's activity. ${ }^{11}$ Additionally, all emotions, even morally neutral emotions like the Seven, can become good through one's careful self-cultivation and balanced regulation of the aroused emotions. Kobong also pointed out that Toegye's libal is not compatible with Zhu Xi's general distinction between $l i$ and $q i$ : $L i$ does not have any physical form and, therefore, does not assume any active physical function. ${ }^{12}$ Therefore, $l i$ does not have any causal efficacy even though it may provide the underlying nature or governing order of the Four. ${ }^{13}$

After Toegye and Kobong's initial rounds of discussion, the debate continued with Yulgok's and Ugye's exchange. Yulgok followed Kobong's view. Yulgok (栗谷, Yi I 李珥 1537-1584) argued for $l i$ and $q i$ 's combined and unified causation of emotions whether they are morally specific or not and argued against Toegye's distinction between the Four and the Seven on the basis of his (Yulgok's) rejection of $l i$ 's exclusive contribution to or generation of the Four. Ugye (牛溪, Seong Hon 成渾 1535-1598) followed Toegye's view on libal (理發) as the unique moral signature that distinguishes the Four from the Seven. He argued that, without li's critical contribution to the Four, the distinction between the Four and the Seven could not be maintained.

In this debate, Toegye focused on li's critical role in the intrinsic moral nature of the Four. He believed that $l i$ contributes to the intrinsic goodness of the Four, which is different from the Seven's "accidental" or "circumstantial" moral nature. The Four are always good. The Seven can become good but they are not always good. To Kobong and Yulgok, however, Toegye's view implied that

8 For a full explanation of the historical and philosophical background of the Four-Seven Debate, see (Ahn 2009a, 2009b). For a book-length discussion of the Four-Seven Debate, see (Chung 1996). In what follows, the Four refers to Mencius's four morally specific emotions and the Seven refers to the ordinary, morally neutral emotions listed in the Book of Rites.

9 In this paper, I use the pen names of Korean Neo-Confucian philosophers following the general convention.

10 In his letter to Kobong, Toegye wrote, "Some years ago, when Mr. Chong [Jeong Ji-Un] made his diagram, it included the thesis that the Four Beginnings issue from principle and the Seven Feelings issue from material force. My opinion was that the dichotomy was too stark and would lead to controversy" (Toegye's response to Kobong's first letter) (Kalton 1994, p. 8).

11 Toegye and Kobong disagreed on the contributions of $l i$ and $q i$ to morally specific and morally neutral emotions. Toegye stated that "... The issuance of the Four Beginnings [the Four] is purely a matter of principle and therefore involves nothing but good; the issuance of the Seven Feelings includes material force and therefore involves both good and evil" (Toegye's first replay to Kobong) (Kalton 1994, p. 11). Against Toegye's view, Kobong argued that, "Man's feelings are but one, and what they are as feelings definitely combines principles [li] and material forces [qi] and has both good and evil" (Kobong's second response to Toegye) (Kalton 1994, p. 21).

12 Basically, li does not have physical form (無形) and active function (無). Kobong stated that, "The two [li and qi] are certainly distinct, but when it comes to their presence in actual things, they are certainly mixed together and cannot be separated. It's just that principle is weak while material force is strong; principle has no concrete sign, but material force is physically in evidence" (Kobong's first letter to Toegye) (Kalton 1994, p. 6). See Yulgok's reply to Ugye's sixth letter (Kalton 1994, p. 175).

13 Zhu Xi (Zhu 1997, Zhuxiji 朱喜集 45) stated that one can talk about the movement of li or taiji (太極, the ultimate supreme, the ultimate foundation of all beings) figuratively but, in its original sense, $l i$ or taiji cannot move or affect other things because if they do, they violate the distinction between the two states (i.e., having physical form and not having physical form (形而上下者不可分). $L i$ and taiji are beyond physical forms. They do not have physical forms. Therefore, they do not physically affect other things. 
$l i$ has the power to originate the Four. If $l i$ is understood as the holistic governance or coherence above the physical form (形而上), it does not have the power to generate the affective arousals that are conditioned by local and physical properties of mental processes. That is, the causal power to generate emotional arousals belongs to the physical energy of qi's local activity, not to $l i$ 's universal governance. It seems that Toegye successfully explained the unique moral nature of the Four through li's governing order, but his view on $l i$ 's involvement in the arousal of the Four conflicted with the well-received Neo-Confucian view on li's formal, not causal, nature: $L i$ does not have physical form (無形) and active function (無爲). Although Kobong seriously considered Toegye's view on $l i$ 's and qi's differential contributions to moral emotions, the debate ended with no consensus. Toegye and Kobong could not fully agree on the role $l i$ plays on the generation of the Four.

\section{Analysis of the Four-Seven Debate}

Imagine, in a very simplistic manner, that the difference between the four morally specific and the seven morally unspecific emotions could be explained by $l i$ as the cause of good and $q i$ as the cause of evil as illustrated below. ${ }^{14}$

$$
\begin{array}{lll}
\mathrm{Li} & \text { (governing order, above the form) } & \rightarrow \text { the Four (good) } \\
\mathrm{Qi} & \text { (dynamic force, below the form) } \rightarrow \text { the Seven (evil) }
\end{array}
$$

One may hypothesize that moral goodness comes out of the coherent and intrinsic nature of $l i$, but evilness comes out of the uneven and diverging nature of $q i$, and believe that the correlation between "li-good-Four" and "qi-evil-Seven" is less confusing but more consistent and understandable. However, the moral distinction between good and evil does not smoothly and consistently correlate with $l i$ and $q i$, because both $l i$ and $q i$ are involved in good and evil. It is possible that good things derive from the interactive combination of $l i$ and $q i$ and the Seven, even under the influence of $q i$, can become good. That is, both $l i$ and $q i$ are involved in moral, immoral, and amoral actions and intentions: Everything is under some interaction between $l i$ and $q i$. In other words, good and evil are not directly or consistently correlated with $l i$ and $q i$, respectively. In fact, good and evil are conceptually incommensurable (not sharing any consistent commonalities) with $l i$ and $q i$. One of the reasons why Toegye started the Four-Seven Debate was his awareness of this incommensurability, that good and evil are not clearly and systematically correlated with $l i$ and $q i$ in their contributions to the Four and the Seven. ${ }^{15}$ At the beginning of the Four-Seven Debate, Toegye pointed out the incommensurability when he commented on Jeong Jiun's (鄭之雲, 1509-1561) interpretation of the Four arising from $l i$ and the Seven arising from $q i$ (四端發於理 七情發於氣). ${ }^{16}$ Toegye did not believe that the Four and the Seven are caused directly by $l i$ and $q i$, respectively. Nor did he believe that good and evil are generated directly by $l i$ and $q i$, either. Since $l i$ and $q i$ are the cosmic principle and force, they both are involved in any processes

14 Generally, this view ( $q i$ is the cause of evil) was received widely among Neo-Confucians. For example, by quoting the following passage from the Neo-Confucian Anthology (Jinsilu 傳習錄), Wong (Wong 2009, p. 149) states that “according to the Cheng Brothers the sources of moral badness lie in the native endowment of $q i$, the body, and the inherent desires of human beings." Someone asked Cheng Yi, "Man's nature is originally good. Why is it that some people cannot change?" [Cheng Yi replied], "In terms of their nature, all men are good. In terms of their 'native endowments' (cai, 才), there are the most stupid who do not change. The most stupid are of two kinds, those who do violence to their own nature and those who throw themselves away."

15 See note 10 above (Toegye's response to Kobong's first letter, Kalton 1994, p. 8).

16 Toegye commented on Jeong Jiun's view expressed in Jeong's the Diagram of the Mandate of Heaven (天命圖). Jeong stated that the Four arise from $l i$ and the Seven arise from qi (四端發於理 七情發於氣). On the basis of his understanding of Zhu Xi's statement (四端是理之發七情是氣之發, Zhu 1986, Zhuzi Yulei 53:20a), Toegye corrected Jeong's statement to “the Four originate from $l i$ and the Seven originate from $q i^{\prime \prime}$ (四端理之發 七情氣之發). Jeong focused on the causal generation of the Four and the Seven, but Toegye stressed their different originations (i.e., different natures or founding sources). Later Toegye changed his own view in the process of the Four-Seven debate. 
or properties whether they are good or evil. ${ }^{17}$ That is, the Four-li-good and the Seven-qi-evil are not lined up correlatively as illustrated below.

$$
\begin{array}{ll}
\mathrm{Li}-\mathrm{Qi} & \rightarrow \text { the Four (good) } \\
\mathrm{Li}-\mathrm{Qi} \rightarrow \text { the Seven (good, evil) }
\end{array}
$$

Toegye felt the need to discuss whether Neo-Confucian metaphysics could explain the distinction between the Four and the Seven through $l i$ and $q i$. He wrote a letter to Kobong asking Kobong's view on this matter, and the Four-Seven Debate started.

The incommensurability in the Four-Seven Debate can be explained as follows: A set of two contrastive categories were not correlative with another set of two contrastive categories. In other words, the moral distinction (good, evil) did not correlate with the metaphysical distinction $(l i, q i)$ in a discrete one-on-one fashion. This incommensurability (i.e., lacking common or comparable conceptual elements) posed a formidable challenge to any philosophical attempt to translate good and evil into the language of $l i$ and $q i$, specifically in the context of distinguishing the intrinsically moral emotions and the morally neutral emotions. Korean Neo-Confucians, through their careful analyses and debates, tried to solve or resolve this philosophical challenge by developing their own moral psychological approach within the framework of Neo-Confucian metaphysics of $l i$ and qi, but they did not successfully accomplish their goals because the incommensurable gap between the metaphysical distinction ( $l i$ and $q i$ ) and the moral distinction (good and evil) in human emotions cannot be completely bridged. ${ }^{18}$

As a way to solve the problem, Korean Neo-Confucians, specifically Toegye, used the notions of the original nature (本然之性, the intrinsic and innate human nature) and the qi-affected nature (氣質 之性, the nature affected by qi's activity in a given environment). ${ }^{19}$ Often goodness was explained by the original nature of the human being because $l i$ 's ordered and balanced tendencies are reflected in the original nature. Evil was explained by the qi-affected nature because of $q i^{\prime} s$ deviant activities or diverging tendencies. For example, in many philosophical debates in Korean Neo-Confucianism, moral goodness was explained by benranzhixing /bonyeonjiseong (本然之性, the original, intrinsic nature), but evil was explained by the uneven, unregulated activities of $q$ i in qizhizhixing/gijiljiseong (氣質之 性, the qi-affected nature). ${ }^{20}$ However, the suggested solution did not work completely. Qi does not necessarily stimulate or facilitate evil. Even with qizhizhixing (qi-affected nature), one can become good and the qi-driven emotions such as the Seven can be developed, through the process of harmony and balance, to support and cultivate moral goodness. Additionally, since both the original nature and the $q i$-affected nature derive from the same nature (xing, 性), they are not fundamentally different: They are only different modes of the same foundational nature. Once again, the Four-good and the Seven-evil are not lined up with the two types of natures (i.e., 本然之性 氣質之性). ${ }^{21}$

17 Kobong noted that "if one regards the Four Beginnings as being issued by principle and [hence] as nothing but good, and the Seven Feelings as issued by material force and so involving both good and evil, then this splits up principle and material force and makes them two [distinct] things. It would mean that the Seven Feelings do not emerge from the nature and the Four Beginnings do not mount on material force [to issue]. What such wording conveys cannot but be considered problematic and the later students of the matter will certainly have doubts about it" (Kobong's Letter to Toegye) (Kalton 1994, pp. 4-5).

18 I will explain the nature of this unbridgeable gap in the following section.

19 "Nature" (xing, 性) here means very generally a deeply engrained disposition or trait. It does not necessarily refer to the permanent and essential property of a given species or individual in a Platonic or Aristotelian sense.

20 For example, Toegye once thought that the distinction between the Four and the Seven is similar to the distinction between the original nature and qi-affected nature: He stated that, "Once I thought confusingly that the distinction between the Four and the Seven is similar to the distinction between the original nature and qi-affected nature" (故愚嘗忘以情之有四端七情 之分猶性之本性氣禀之異也) (Yi 1997, vol. 2, pp. 411-12).

21 Later Yi Ik (李瀷 1681-1763, pen name Seong Ho 星湖) argue against the distinction between the original nature and the $q i$-affected nature. He does not believe that human beings have two entirely different forms of nature. The two forms of nature are just two different modes of the same underlying nature founded on li's activity. He simply states that "the original nature and the $q i$ affected nature are not two natures.... The nature is one" (本然之性與氣禀之性 非二性也 .... 性 一也) (Yi 1999; Jeong 2013, p. 46 n16). 


$$
\begin{array}{ll}
\text { 本然之性 (Original, li-governed nature) } & \rightarrow \text { the Four (good) } \\
\text { 氣質之性 (Qi-affected nature) } & \rightarrow \text { the Seven (good, evil) }
\end{array}
$$

Another suggested solution to this incommensurability was to introduce a new element (i.e., the balance and articulation 中節) to Neo-Confucian moral metaphysics. ${ }^{22}$ Good and evil are not directly lined up with $l i$ and $q i$ but derive from the balanced and harmonious articulation (中節) of $l i$ or $q i$. If $l i$ and $q i$ are not balanced and harmoniously articulated (不中節), evil comes out. That is, good and evil are not the matter of $l i$ and $q i$ but the matter of their balance and harmonious articulation. ${ }^{23}$ In fact, $\mathrm{Zhu} \mathrm{Xi}$ stated that moral emotions, whether they are the Four or the Seven, derive from the specific conditions of the balance and articulation. ${ }^{24}$ In other words, good and evil are not directly explained by the presence or absence of $l i$ and $q i$ but by their particular conditions of the balance and articulation in relation to emotions, intentions, and other psychological or situational contexts.

$$
\begin{array}{lll}
\text { 中節 } & \text { (balance-articulation in } l i q i) & \rightarrow \text { the Four (good) } \\
\text { 中節/不中節 } & \text { (balance-articulation or its absence in } l i q i) & \rightarrow \text { the Seven (good, evil) }
\end{array}
$$

This explanation, however, is not successful because the standard of the balance and articulation needs to be provided independently of or in addition to the activity or interactivity of $l i$ and $q i$. Why are certain (i.e., balanced or articulated) activities or processes of $l i$ and $q i$ good while others are not good? It seems that the answer to this question should be found somewhere other than $l i$ and $q i$, since good and evil are not determined by $l i$ and $q i$ alone but by their specific patterns of activity. That is, in order to explain good and evil, the Cheng-Zhu Neo-Confucianism had to offer a formal principle regarding the optimally balanced pattern of $l i$ and $q i$ outside of $l i$ and $q i$. If one takes this solution, however, one has to give up the completeness of Neo-Confucian $l i-q i$ metaphysics because one has to find the foundation of good and evil outside of $l i-q i$ metaphysics or make it circular or redundant if one, in order to maintain the completeness of $l i$-qi metaphysics, uses $l i$ and $q i$ to explain the balance between $l i$ and $q i$. It seems that Neo-Confucian $l i-q i$ metaphysics failed to provide a full and satisfactory explanation of good and evil through the process of the balance and articulation.

As these conflicting viewpoints and the failed consensus show, the Four-Seven Debate revealed the fundamental limitation of the Cheng-Zhu Neo-Confucianism in its explanation of the mind and morality: $L i$ and $q i$ are morally indiscrete, but the mind can be morally specific with some of its spontaneous emotions. It became quite clear at the end of the debate that Neo-Confucian li-qi metaphysics provided only limited explanations on the goodness of the mind and its emotions. Both Toegye and Kobong, in their heated debates on moral emotions, knew the incompleteness and inconsistency of Neo-Confucianism and did their best to provide their own explanations for how the cosmic principles and processes of $l i$ and $q i$ give rise to moral emotions and virtues. Yet, as I discussed in this section, the incommensurability of metaphysical terms (such as $l i$ and $q i$ ) and moral terms (such as good and evil) cannot be easily resolved unless Neo-Confucian $l i-q i$ metaphysics is fully revised or even abandoned. The revision, or in some cases gradual abandonment, of Cheng-Zhu's

22 In the Doctrine of the Mean (Zhongyong 中庸), there is a passage where the balance and articulation (中節) are mentioned: "The state before the arousal of pleasure, anger, sorrow, or joy is called balance (中). When they are aroused with balance and articulation, they are called harmony (和)” (喜怒哀樂之未發謂之中 發而皆中節謂之和).

23 When emotions reach their due measure, they achieve heavenly harmony and goodness. For example, Kobong stated that, "Although the Seven can be categorized as $q i, l i$ is already included in it. When they issue and reach their due measure, they are called heavenly endowed nature and the original substance. In that case, how can they be regarded as issuing from qi and be different from the Four?" (Yi 1997, 1:440b, 441a). However, Kobong also believed that even the Four can be unbalanced or unharmonized in actual experience of the Four (Hong 2014, p. 274). That is, to Kobong, harmony and disharmony were a more important distinction than intrinsic and accidental goodness of the Four and the Seven in the moral psychology of emotion.

24 Zhu Xi (Zhu Xi Yulei, 53) states that "regarding the moral emotions of pity/compassion and shame/dislike, there are balance/harmony and imbalance/disharmony. It is as if there are appropriate and inappropriate pity/compassion and appropriate and inappropriate shame/dislike depending on their balance and harmony" (惻隱羞惡也有中節不中節 若不當 惻隱而惻隱 不當羞惡而羞惡 便是不中節). 
Neo-Confucian $l i-q i$ metaphysics is exactly what one can witness in the later development of Korean philosophy in the 18th and 19th centuries.

\section{The Theistic Turn in Korean Philosophy}

In the Cheng-Zhu Neo-Confucianism, moral properties such as good and evil were explained by the cosmic or metaphysical properties and interactivities of $l i$ and $q i$. However, the two types of categories (metaphysical and moral categories), as I analyzed above, do not correlate consistently and coherently, and the relations between the mind (xin), nature (xing), and moral goodness are not fully explained by the metaphysical framework of $l i$ and $q i$. In the 18th and 19th centuries, through the Practical Learning school (sirhak 實學) of Jeong Yakyong (pen name Dasan 茶山, 1762-1836) and the school of Donghak (東學, the Eastern [i.e., Korean] Learning, a philosophical school and a religious social movement founded by Choi Je-wu [崔濟愚, 1824-1863]), some Korean philosophers finally settled on a solution or a resolution to the challenging philosophical issues of Neo-Confucianism. ${ }^{25}$ They discussed an independent foundation of morality (i.e., a different type of moral authority outside of the original nature [本然之性] or the $l i$-driven nature of the Four) and a new philosophical viewpoint that can replace the Cheng-Zhu Neo-Confucianism. ${ }^{26}$

Inspired and influenced by the theology and philosophy of Roman Catholicism imported from China, Dasan found the moral authority (i.e., the normative and practical standard) in Sangje (上帝, the Lord or the Emperor on High). ${ }^{27}$ He stated that "li cannot stand on its own. Therefore, it does not have the power [the Way] to generate physical difference." ${ }^{28}$ More specifically, he argued that "li is intrinsically devoid of responsiveness and active authority. If that is the case, is there anything one should be seriously cautious and fearful of?"29 Additionally, Dasan criticized the relevance of $l i-q i$ metaphysics in the moral discourse. He stated that,

People today respect, praise and honor xing [性] as if it is as great as Heaven when they integrate it with the theory of taiji [太極, the ultimate supreme, the ultimate foundation of all beings] yin yang [陰陽, negativity and positivity, the two alternating forces or movements in the universe] and combine it with the original and the qi-affected natures [本然氣質] in a confused, deceptive, illusive, and exaggerated manner. They think they analyzed minute distinctions in the secretive details of Heaven and human beings but they fail to use them to promote the practical values of ordinary life. It is impossible not to notice the confusion. ${ }^{30}$

In addition to Dasan's philosophy, the collapse of Neo-Confucian moral metaphysics can be observed in Donghak. Donghak found a non-Neo-Confucian foundation in Hanulnim (Heavenly Being) or Cheonju (天主, Heavenly Lord). Hanulnim is a divine and personal, but not completely

25 For example, (Kim 2015, p. 563) stated that to explain practical effectiveness and moral efficacy, direct moral authority is necessary in Neo-Confucian thought. That is, beyond $l i$ and $q i$, Korean Neo-Confucians felt a need to develop a separate foundation for morality. "Tasan [Dasan] put the Lord on High in the place of $l i$ for the very practical reason that people had ceased to acknowledge the authority of $l i$. He took this stance of putting practical effectiveness above logical consistency, but it was not just because he was a scholar of the Practical Learning School (Sirhak) in the late Choson [Joseon] Dynasty. This viewpoint is also found in the discussions by Neo-Confucian scholars in the early Choson [Joseon] Dynasty, such as the debates on the Four Beginnings and the Seven Emotions. In that sense, the effectiveness for realizing Confucian ideals is often more decisive than theoretical consistency in the formation of theories or arguments in Confucianism or Neo-Confucianism, even though it cannot be denied that logical consistency or theoretical preciseness are important for the validity of Confucian theories, given that the goal of theoretical debates in Confucianism is the actualization of moral life and realization of an ethical society."

26 (Takahashi 1929/2001), a Japanese Neo-Confucian scholar in the early 20th century, believed that Dasan was faithful to the spirit of Toegye's philosophy that emphasized the primacy of moral philosophy over and beyond the $l i-q i$ cosmology of Zhu Xi's Neo-Confucianism. See (Kim 2010) for further discussion.

27 For the broad historical background of Dasan's philosophy, see (Baek 2012).

28 “理非自植者 故無先發之道也” 與猶堂全書 中庸講義補 (Jeong 2002; Jeong 2013, p. 59 n59).

29 “理本無知 亦無威能 何所戒而之 何所恐而懼之乎” (Jeong 2002, p. 282, 49a).

30 “今人推尊性字, 奉之天樣大物, 混之以太極陰陽之説, 雜之以本然氣質之論, 眇芒幽遠, 恍忽夸誕. 自以毫分縷析, 窮天人不發 之秘, 而卒之無補於日用常行之則, 亦何益之有矣. 斯不可以不辨” (Jeong 2002; Jeong 2013, p. 61 n63). 
transcendental, being. It is an ultimate and immanent moral authority in the mind and the world outside. ${ }^{31}$ Choi was very intentional on the fundamental connection or penetration between the mind and Hanulnim (the divine moral authority) in his philosophy of Donghak. ${ }^{32}$ Considering the heavily stratified social structure of the Joseon dynasty, Donghak's vision of universal equality and the fundamental unity between the mind, the world, and the divine being was simply revolutionary (Kim 2002; Park 2015). Specifically, its egalitarian and humanistic tendency was not only expressed in its philosophy but also reflected in its religious rituals and codes of conduct. According to (Kim 2015), the leaders of Donghak (i.e., Choi Je-Wu and Choi Sihyeong (崔時亨1827-1898)) developed and implemented rules of equality and respectful behavior to fellow humans in Donghak rituals and the common conduct of Donghak followers. All followers of Donghak, regardless of their social statuses, gender, wealth, and education, could participate in Donghak rituals and could serve the leadership positions (Kim 2015). Choi Je-wu called his disciples friends, and Choi Sihyeong appointed a person from the lowest class to one of the major Donghak leadership positions.

Although both Dasan's Sirhak and Choi's Donghak were influenced by the Confucian philosophy of self-cultivation and moral excellence of virtue, they focused on the practical (not just the metaphysical) order of the universe and the independent and universal authority of morality. That is, their philosophical viewpoints significantly deviated from the two major Neo-Confucian convictions, the governing order of $l i$ throughout the universe and the $l i$-driven nature of moral authority. Specifically, in both schools of Korean philosophy, moral properties were not regarded as properties derived from $l i$ and $q i$ but as one of the original properties of the world that derive from their own foundation and justification independent of $l i$ and $q i{ }^{33}$ Instead of explaining what is good or what one should do from the perspective of what is out there at the foundation of universe, these later schools of Korean philosophy and religion explained good and evil directly from the perspective of the ultimate and independent moral authority that we can refer to and respectfully emulate in our actions and decisions independently of Neo-Confucian metaphysics.

As the theistic orientation of the Practical Learning and the Eastern Learning demonstrate, many Korean philosophers attempted to explain the intrinsic and nonderivative nature of morality and secured the foundation of the practical moral mind through the independent standard of practically effective and universal normativity. Reliance on the authority of a divine figure such as Sangje (上 帝, the Emperor on High), Hanulnim(한 울 님, Heavenly Being), or Cheonju (天主, Heavenly Lord), therefore, can be understood in this philosophical context of the theistic turn (i.e., a theistic way to solve philosophical problems regarding the nature of the universe, the mind, and morality). ${ }^{34}$

On the one hand, this theistic tendency seems to be an anachronistic or irrational solution to the problems of moral issues and distinctions. Divine authority such as Heaven (天) was not entirely foreign to Chinese and Korean traditions, but the theistic solution to moral issues seemed unprecedented or even unacceptable. Classical Confucian philosophers such as Mencius talked about Heaven (天 tian) as the ultimate justification of moral goodness (Mencius, 7A1), but Heaven is not a moral agent or a personal god, ${ }^{35}$ nor does it refer to a realm of divinity. Neo-Confucian philosophers such as Zhou Dunyi (周敦䫤, 1017-1073) developed a universal and systematic explanation of the

31 Hanul (한 울) means heaven, oneness, and unity. The two major teachings of Donghak (東學, the Eastern Learning) are (a) serving and respecting the Heavenly Lord (侍天主) and (b) recognizing the oneness of human being and Heaven (人乃天).

32 See Lee's (Lee 2017) discussion of Choi Je-wu's Donghak philosophy and its practical moral orientation.

33 In his discussion of the practical learning (Sirhak) school, Choe Namseon (崔南善) (Choe 1930) identified two subsections of the Sirhak school, introspective practical philosophy and political economical philosophy. Both Seongho's (Yi Ik's) and Dasan's (Jeong Yakyong's) discussions of moral psychology and cultivation belonged to the former subsection of Sirhak.

34 This type of theistic orientation can be found in Nakae Toju's (中江藤樹, 1608-1648) philosophy from the perspective of Yangming Neo-Confucianism. See (Bodart-Bailey 1997, p. 670). Although there are some comparable philosophical orientations, Dasan and Choi Je-wu were not Yangming Neo-Confucians.

35 Mencius stated (7A1) that, "To preserve one's mental constitution, and nourish one's nature, is the way to serve Heaven" (存其心 養其性 所以事天也). 
universe through taiji, $l i$, and $q i$, but they are not theistic divine figures. ${ }^{36}$ A well-known Korean Neo-Confucian's (Shin Hudam [愼後聑, pen name Habin 河賓, 1702-1762]) criticism of Catholicism (the Western Learning, 西學) clearly articulated this type of philosophical concern. Habin argued that cultivation of goodness and discussion of right and wrong on the basis of a theistic religion (Catholicism) and its divine authority are not recommendable because our moral effort and cultivation of virtue, under the theistic framework, derive from the selfish and instrumental interest of insim (人 心, the human mind with personal interests and desires). If people cultivate their virtues in order to be rewarded by God or gods in the afterlife, their moral intention is compromised by their pursuit of personal profit (利), which is a major Confucian evil. Habin believed that the Western Learning (i.e., Catholicism) promotes this type of selfish interest, which goes against the ideal moral vision of Confucianism (i.e., a sense of duty and compassion embedded in the Confucian heart-mind). ${ }^{37}$ He also argued that the notion of Shangdi or Sangje (上帝, the Emperor on High) as a governor god existed in classical Confucianism but it is not a creator god. The notion of a creator god, specifically with the ability to create the universe out of nothing (creatio ex nihilo), was completely foreign to Confucianism. ${ }^{38}$

On the other hand, this theistic orientation in Korean philosophy in the 18th and 19th centuries can be understood broadly as a philosophical pursuit of a universal, rational, and practical ground of morality in a world full of practical concerns and moral challenges. Dasan found the judge and the enforcer of moral goodness in the personal God of Christianity. ${ }^{39}$ God provides the standard of right and wrong (i.e., the standard of normativity), and promotes moral goodness (practical efficacy), which, as I explained above, many Korean Neo-Confucians attempted to explain and articulate over several hundred years of philosophical debates. If the intrinsic nature of morality could not be explained by $l i$ and $q i$ in the nature (xing 性), the mind (xin 心), and the emotions (qing 情), it should be found somewhere else. The notion of divine authority, perhaps, provides a viable solution to many philosophical and moral confusions and challenges that Korean Confucians had to face in the Joseon Korea.

Perhaps, from a broad philosophical viewpoint, the theistic turn in Korean philosophy (i.e., finding a non-derivative divine moral authority to overcome the philosophical limitations of the $l i-q i$ metaphysics of Neo-Confucianism) can be understood from the perspective of rationalized religion, a philosophy of religion developed by Kant (1793/1998) in his Religion within the Boundaries of Mere Reason. Kant argued that a religion, specifically Christianity, could be rationally accepted and practiced through the clear articulation and unification of morality and the ultimate goals of life. He stated that morality "inevitably leads to religion, and through religion it extends itself to the idea of a mighty moral lawgiver outside the human being in whose will the ultimate end (of the creation of the world) is what can and at the same ought to be the ultimate human end" (Kant 1793/1998, p. 35-36, 6:6). Against the background of the Kantian ideal of rationalized religion, the unique theistic orientation of Korean philosophy can be understood as a philosophical solution to many limitations and ambiguities of Neo-Confucianism on the identification and distinction of moral properties from other properties of the world. If the normative standard of good and evil cannot be consistently or fully explained by $l i$, qi, and their interaction, a different foundation of moral value and authority should be considered and pursued. Some Korean Neo-Confucians (such as Dasan and other Neo-Confucians in the school of Practical Learning) in the 18th and 19th centuries did just that. As the name suggests, the school of Practical Learning (Sirhak 實學) emphasized the empirical and pragmatic understanding of the world over metaphysical or cosmological speculation. When it comes to the foundation of morality, Practical Learning challenged Neo-Confucian $l i-q i$ metaphysics through its emphasis on the direct moral efficacy

\footnotetext{
See (Adler 1999) and (Wang 2005) for full details of Zhou Dunyi's Neo-Confucian philosophy and cosmology.

See (Choi 1988, p. 204-5).

See (Choi 1988, p. 240).

See (Baker 2004, 2013) for further details of Dasan's philosophy and its interaction with Catholicism.
} 
of the mind and its normative standard derived from divine authority. ${ }^{40}$ That is, instead of finding the root of morality in transcendental metaphysics or formal principles, some Korean philosophers, specifically those of the Practical Learning (Sirhak) school, pursued an independent and intrinsic foundation of goodness in theistic moral authority.

\section{Conclusions}

In this paper, I discussed how Korean Neo-Confucians in the Joseon dynasty understood the moral concepts and moral emotions in their debates, specifically in the Four-Seven Debate. According to many Korean Neo-Confucians in the Joseon dynasty, the cosmology and metaphysics of Neo-Confucianism, because of its preoccupation with the cosmic process that encompasses the mind, morality, and the intrinsic goodness of the universe, could not successfully explain the moral and immoral tendencies of the mind and its emotions. If the whole universe is generated and governed by the same ultimate foundations such as taiji, yin-yang, wuxing (五行, the five cosmic elements), and $l i-q i$, why are some emotions inherently good but others are only accidentally good? Why and how do morally deviant intentions and emotions exist? The Four-Seven Debate is a perfect example where these serious philosophical questions were discussed in the context of the moral goodness of the mind and its emotions. Since emotion is an aroused state of the mind, $q i$ should be critically involved. Then, how can one explain the goodness of the innately given moral emotions (if $q i$ has a deviant tendency but its active energy is needed for their arousal)? This conflict between Neo-Confucian $l i-q i$ metaphysics and moral psychology of the innately good emotions is the main debating point of the Four-Seven Debate. As I discussed in the previous sections, the conflict was not fully resolved, and the gap between moral metaphysics and moral psychology was not completely bridged because of the inherent logical gap or the incommensurability between Neo-Confucian li-qi metaphysics and the moral psychology of the Confucian heart-mind.

The philosophical effort of the Korean Neo-Confucians to explain the moral goodness of the mind and its emotions, however, is not necessarily a meaningless or useless dream. They sharpened the conflict between the moral metaphysics and the moral psychology of Neo-Confucianism, developed different interpretations of the moral emotions, and gradually revealed the philosophical limitations of Neo-Confucian $l i-q i$ metaphysics. They found two general ways to overcome this philosophical challenge. First, they chose and studied moral psychology of emotion and pursued the practical foundation of morality instead of exploring and finding solutions from the viewpoint of $l i-q i$ metaphysics. For example, philosophical debates following the Four-Seven Debates, such as the Horak Debate, provided rigorous philosophical analyses of moral psychology. Second, some Korean Neo-Confucians also searched for a direct and independent moral authority outside of the Neo-Confucian universe (i.e., the universe of taiji, yin yang, wuxing, and $l i-q i$ ). The standard of right and wrong, for these philosophers, did not derive from $l i$ and $q i$ but from an independent divine source (such as the Emperor on High (上帝), or Hanulnim). Korean Neo-Confucianism in the Joseon dynasty, therefore, can be understood from the perspective of Korean philosophers' efforts to bring the moral goodness of the mind to the foreground of ethics and to establish a practical and universal moral authority for everyone. From this viewpoint, the Four-Seven Debate was an inspiring starting point of the moral psychological and theistic turn of Korean philosophy in the Joseon dynasty.

Funding: This research received no external funding.

Conflicts of Interest: The author declares no conflicts of interest.

40 For example, in the same philosophical school, Dasan's senior Yi Ik (pen name Seongho, 1681-1763), emphasized the moral will and intention of an agent and gave up the strict distinction between the Four and the Seven on the basis of $l i$ 's and qi's differential contributions to human emotion. See (Jeong 2013, pp. 49-50). 


\section{References}

Adler, Joseph A. 1999. Zhou Dunyi: The Metaphysics and Practice of Sagehood. In Sources of Chinese Tradition, 2nd ed. Edited by Wm. Theodore de Bary and Irene Bloom. New York: Columbia University Press, vol. 1, pp. 669-78.

Ahn, Young-sang. 2009a. A Study on the Joseon Neo-Confucian's Four-Seven Debate, Comparing it with the Yangminng School's Debate about Equilibrium in the Meditation and Harmony in the Practice. Korean Classics Studies 51: 615-53. (In Korean)

Ahn, Young-sang. 2009b. An Exploration on Zhu Xi's the Theory of Mind's Consolidating Nature and the Emotions for Understanding Four-Seven Debate. Study of Philosophy and Culture 32: 281-308. (In Korean)

Angle, Stephen. 2009. Sagehood: The Contemporary Significance of Neo-Confucian Philosophy. New York: Oxford University Press.

Angle, Stephen. 2012. Contemporary Confucian Political Philosophy: Toward Progressive Confucianism. Malden: Polity Press. Angle, Stephen, and Justin Tiwald. 2017. Neo-Confucianism: A Philosophical Introduction. Malden: Polity Press.

Baek, Min Jeong. 2012. Jeong Yakyong's Philosophy and 18th century East Asia. Horizon of Knowledge 12: 200-12. (In Korean)

Baker, Don. 2004. Tasan between Catholicism and Confucianism: A Decade under Suspicion, 1791 to 1801. Tasanhak 5: 55-86.

Baker, Don. 2013. Finding God in the Classics: The Theistic Confucianism of Dasan Jeong Yagyong. Dao. A Journal of Comparative Philosophy 12: 41-55. [CrossRef]

Bodart-Bailey, Beatrice. 1997. Confucianism in Japan. In Companion Encyclopedia of Asian Philosophy. Edited by Brian Carr and Indira Mahalingam. New York: Routledge, pp. 660-74.

Bol, Peter K. 2008. Neo-Confucianism in History. Cambridge: Harvard University Asia Center.

Chan, Joseph. 2014. Confucian Perfectionism: A Political Philosophy for Modern Times. Princeton: Princeton University Press.

Ching, Julia. 2000. The Religious Thought of Chu His [Zhu Xi]. New York: Oxford University Press.

Choe, Namseon. 1930. Sirhak. Dong-A Daily News, 3406, Section 4. February 8. (In Korean)

Choe, Young Jin. 2009. A Study of the Mentalizing (xinxue 心學) Tendencies of Korean Neo-Confucianism in the 18th to 19th Century. Korean Folk Culture 33: 339-68. (In Korean)

Choi, Dong-Hee. 1988. Korean Sirhak's Response to the Western Learning. Seoul: Folk Culture Institute, Korean University. (In Korean)

Chung, Edward. 1996. The Korean Neo-Confucianism of Yi Toegye and Yi Yulgok: A Reappraisal of the "Four-Seven Thesis" and Its Practical Implications for Self-Cultivation. New York: State of New York Press.

Hong, Seongmin. 2014. On Appropriateness of Moral Emotion in Gi Daeseung's [Kobong's] Philosophy. Korea Study 48: 267-93. (In Korean)

Huang, Yong. 2014. Why Be Moral? Learning from the Neo-Confucian Cheng Brothers. Albany: The State University of New York Press.

Hume, David. 1739/1975. A Treatise of Human Nature, 2nd ed. Edited by L. A. Selby-Bigge. Revised by P. H. Nidditch. Oxford: Clarendon Press.

Jeong, So-yi. 2013. A Study of the Continuity and Discontinuity of Toegye Yi Hwang's, Seongho Yi Ik's and Dasan Jeong Yakyong's Theories of Mind. Human, Environment, and Future 10: 37-70. (In Korean)

Jeong, Weon-jae. 2016. Does the Neo-Confucianism of the Chosŏn Dynasty belong to the Cheng-Zhu School? Rethinking the Intellectual History of Chosŏn through the Philosophical Tradition of Yi I (1538-1584). Journal of Korean Religions 7-1: 67-92. [CrossRef]

Jeong, Yakyong. 2002. Yoyudang Jeonseo (與猶堂 全書 Complete Works of Jeong Yagyong). Seoul: Korean Classics Research Institute.

Kalton, Michael. 1994. The Four-Seven Debate, an Annotated Translation of the Most Famous Controversy in Korean Neo-Confucian Thought. Albany: SUNY Press.

Kant, Immanuel. 1793/1998. Religion within the Boundaries of Mere Reason. Translated and edited by Allen Wood and George Di Giovanni. New York: Cambridge University Press.

Kim, Choon Sung. 2002. Donghak: Towards Life and Spirituality. Korea Journal 42: 158-86. 
Kim, Hyoungchan. 2015. The li-ki [li-qi] Structure of the Four Beginnings and the Seven Emotions and the Intention of the Four-Seven Debate: A Critical Reflection on the Methods of Explaining the Theories of the Four Beginnings and the Seven Emotions in Korean Neo-Confucianism. Acta Koreana 18: 561-81.

Kim, Jeongin. 2015. Origination and Development of Donghak. In History toward Democracy: Rediscovery of the 19th Century Korean History. Seoul: With Books Publishing. (In Korean)

Kim, Sungmoon. 2014. Confucian Democracy in East Asia: Theory and Practice. New York: Cambridge University Press.

Kim, Tae Nyun. 2010. From Record of Philosophical Lineage (學案) to History of Philosophy: Viewpoints and Historiography of Korean Neo-Confucianism. Korean Studies 23: 41-84. (In Korean)

Lee, Cheol-Seung. 2017. Moral Consciousness Appeared in Donghak Thought. Inmoonhak Yeongu 54: 107-30. (In Korean)

Makeham, John, ed. 2010. Dao Companion to Neo-Confucian Philosophy. New York: Springer.

Moore, George Edward. 1903/2004. Principia Ethica. Mineola: Dover Publications.

Park, Hongsik. 2015. A Meaning of Donghak in the History of Korean philosophy. Journal of East-West Humanities 4: 1-29. (In Korean)

Takahashi, Dorou. 1929/2001. The Li School and the Qi School in the History of Korean Neo-Confucianism. Translated by Hyeong-seong Yi. Seoul: Yemoon Seowon. (In Korean)

Tan, Sor-Hoon. 2004. Confucian Democracy: A Deweyan Reconstruction. Albany: State University of New York Press. Wang, Robin. 2005. Zhou Dunyi's Diagram of the Supreme Ultimate Explained: A Construction of the Confucian Metaphysics. Journal of the History of Ideas 66: 307-23. [CrossRef]

Wong, Wai-Ying. 2009. Morally Bad in the Philosophy of the Cheng Brothers. Journal of Chinese Philosophy 36: 141-56. [CrossRef]

Yi, Hwang. 1997. Jeungbo Toegye Jeonseo (Complete Works of Yi Hwang). Seoul: Sungkyunkwan University Press, vol. 1-5.

Yi, Ik. 1999. Sachil Shinpyun 四七新編 (A New Edition of The Four Seven Debate). Translated by Sangik Yi. Seoul: Daunsam. (In Korean)

Zhu, Xi. 1986. Zhuzi Yulei (朱子語類, Classified Conversations of Master Zhu). Beijing: Zhonghua Shuju.

Zhu, Xi. 1997. Zhu Xi Ji (朱喜集, Collected Works of Zhu Xi). Edited by Guo Qi. Cheng Dao: Sichuan Education Press.

(C) 2018 by the author. Licensee MDPI, Basel, Switzerland. This article is an open access article distributed under the terms and conditions of the Creative Commons Attribution (CC BY) license (http:/ / creativecommons.org/licenses/by/4.0/). 